\title{
Technical Note: Temporal change in averaging kernels as a source of uncertainty in trend estimates of carbon monoxide retrieved from MOPITT
}

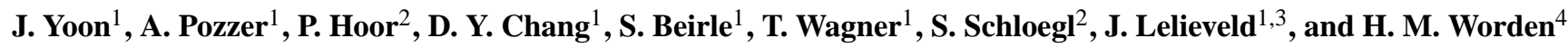 \\ ${ }^{1}$ Atmospheric Chemistry Department, Max-Planck Institute of Chemistry, P.O. Box 3060, 55020 Mainz, Germany \\ ${ }^{2}$ Institute of Atmospheric Physics, Johannes Gutenberg University, 55099 Mainz, Germany \\ ${ }^{3}$ The Cyprus Institute, Energy, Environment and Water Research Center, P.O. Box 27456, 1645 Nicosia, Cyprus \\ ${ }^{4}$ National Center for Atmospheric Research (NCAR), Boulder, CO, USA \\ Correspondence to: J. Yoon (jongmin.yoon@mpic.de)
}

Received: 18 June 2013 - Published in Atmos. Chem. Phys. Discuss.: 5 August 2013

Revised: 1 October 2013 - Accepted: 18 October 2013 - Published: 21 November 2013

\begin{abstract}
It has become possible to retrieve the global, longterm trends of trace gases that are important to atmospheric chemistry, climate, and air quality from satellite data records that span more than a decade. However, many of the satellite remote sensing techniques produce measurements that have variable sensitivity to the vertical profiles of atmospheric gases. In the case of constrained retrievals like optimal estimation, this leads to a varying amount of a priori information in the retrieval and is represented by an averaging kernel (AK). In this study, we investigate to what extent the estimation of trends from retrieved data can be biased by temporal changes of averaging kernels used in the retrieval algorithm. In particular, the surface carbon monoxide data retrieved from the Measurements Of Pollution In The Troposphere (MOPITT) instrument from 2001 to 2010 were analyzed. As a practical example based on the MOPITT data, we show that if the true atmospheric mixing ratio is continuously $50 \%$ higher or lower than the a priori state, the temporal change of the averaging kernel at the surface level gives rise to an artificial trend in retrieved surface carbon monoxide, ranging from -10.71 to $+13.21 \mathrm{ppbv} \mathrm{yr}^{-1}$ ( -5.68 to $\left.+8.84 \% \mathrm{yr}^{-1}\right)$ depending on location. Therefore, in the case of surface (or near-surface level) CO derived from MOPITT, the AKs trends multiplied by the difference between true and a priori states must be quantified in order to estimate trend biases.
\end{abstract}

\section{Introduction}

Since the Industrial Revolution human activity has brought about a significant change in atmospheric trace gas concentrations (Hansen et al., 2007), which has important consequences for global air quality and the earth's atmosphere radiative budget, thus causing climate change (Forster et al., 2007, IPCC AR4). One of the most important trace gases is carbon monoxide (CO). It is produced by the oxidation of methane $\left(\mathrm{CH}_{4}\right)$ and non-methane hydrocarbons (NMHC), and directly emitted by biomass burning and combustion of fossil fuels (Wallace and Hobbs, 2006). It acts as a major sink for the tropospheric hydroxyl radical $(\mathrm{OH})$ (Crutzen, 1974). OH, in turn, regulates the lifetimes of various tropospheric trace gases (Khalil and Rasmussen, 1990; Wallace and Hobbs, 2006). The oxidation of $\mathrm{CO}$ also leads to the formation of carbon dioxide $\left(\mathrm{CO}_{2}\right)$ and tropospheric ozone $\left(\mathrm{O}_{3}\right)$ (Crutzen and Gidel, 1983; Fishman and Crutzen, 1978; Burrows et al., 1995). Because of its moderately long lifetime (weeks to months) and inhomogeneous distribution in the troposphere, $\mathrm{CO}$ is an ideal tracer for monitoring the air pollution sources and transports (Cicerone, 1988; Logan et al., 1981; Shindell et al., 2006; Lelieveld et al., 2001; Hoor et al., 2005; Edwards et al., 2004, 2006; Pan et al., 1995; Worden et al., 2013a; Liu et al, 2011, 2013).

Remote sensing from satellites provides the unique opportunity to study regional and global changes in atmospheric composition (Burrows et al., 2011). Since its launch on board the EOS-Terra satellite in 1999, MOPITT has provided 
global and long-term $\mathrm{CO}$ products, which may be used to estimate trends of tropospheric $\mathrm{CO}$ and the influence of anthropogenic emissions on atmospheric chemistry (Worden et al., 2013a). To retrieve CO vertical profiles using MOPITT observations, the theory developed by Rodgers (1976, 2000) is employed in the retrieval algorithm (Pan et al., 1998; Deeter et al., 2003). The algorithm is designed to use a priori profiles derived from a climatology based on simulations by the Model for Ozone and Related chemical Tracers-4 (MOZART-4) model (Pan et al., 1998; Deeter et al., 2003; Deeter, 2009; Worden et al., 2013a). The retrieval sensitivity is generally evaluated through averaging kernels (AKs) (Pan et al., 1998; Rodgers, 2000; Deeter et al., 2003; Eskes and Boersma, 2003). The AKs are essential for meaningful comparisons of satellite products against in situ data and model results (Rodgers, 2000; Rodger and Connor, 2003; Eskes and Boersma, 2003). However, we will show that their temporal change can lead to a significant error in the trend estimation of retrieved CO.

The goal of this paper is to investigate the uncertainty caused by temporal AKs change in the trend estimation of retrieved state. It is shown that without adequate knowledge of the differences between the a priori and true profiles of the observed trace gases, AKs uncertainty cannot be eliminated in the trend estimation of retrieved state. Although MOPITT monthly surface $\mathrm{CO}$ data were used in this study, we emphasize that the uncertainties in trend estimations apply to any remote sensing observations based on similar AKs concepts.

In Sect. 2, the MOPITT CO data and the standard method used for trend estimation are described. Section 3 presents the analysis of uncertainties and a practical example based on MOPITT CO surface data. Section 4 analyzes possible issues associated with statistically merging Level 3 MOPITT data, and Sect. 5 summarizes this work and presents conclusions.

\section{MOPITT surface $\mathrm{CO}$ and linear trend model}

The MOPITT instrument on the EOS-Terra spacecraft provides tropospheric $\mathrm{CO}$ and $\mathrm{CH}_{4}$ distributions on a global scale (Deeter et al., 2003). The temperature constraints of the MOPITT radiometric calibration (University of Toronto and NCAR MOPITT Team, 1996, MOPITT ATBD) are $\pm 0.5 \mathrm{~K}$ for the $\mathrm{CO}$ profile channels and $\pm 1 \mathrm{~K}$ for the $\mathrm{CO}$ and $\mathrm{CH}_{4}$ column channels for the expected precisions, being $10 \%$ for $\mathrm{CO}$ and $1 \%$ for $\mathrm{CH}_{4}$ products (Pan et al., 1995, 1998). The global MOPITT retrieved CO data have been used for estimating CO distributions, atmospheric transport, sources, and sinks (e.g., Drori et al., 2012; Fortems-Cheiney et al., 2011; Hooghiemstra et al., 2011; Kanakidou et al., 2011; Arellano and Hess, 2006; Choi and Chang, 2010; Stroppiana et al., 2010). Recently the MOPITT Version 5 (V5) Level 3 (L3) thermal infrared (TIR) retrievals (in daytime) lead to an improved sensitivity for the lower tropospheric CO retrieval, a reduced retrieval bias drift associated with long-term in- strumental degradation, and a more exact representation of the effects of random errors in the radiances (Clerbaux et al., 2009; Worden et al., 2010, 2013a; Deeter et al., 2007a, 2011, 2012, 2013), and are used in this study. Figure 1 shows the global mean distribution of monthly surface $\mathrm{CO}$ products (spatial resolution: $1^{\circ} \times 1^{\circ}$ ) from 2001 to 2010 .

The linear trends $(\omega)$ in a unit of $\mathrm{ppbv} \mathrm{yr}^{-1}$ are estimated using a linear least squares fit based on monthly data as follows:

$y_{t}=\omega x_{t}+\tilde{y}^{m}+n_{t}+\mu$,

where $x_{t}, \mu, n_{t}$, and $\tilde{y}^{m}$ denote the time index term $(t / 12)$, the constant term, the monthly noise for the analyzed periods $(t=1 \ldots T)$, and the monthly climatology mean of $y_{t}(m=$ 1 ...12) (i.e., the climatological monthly varying pattern), respectively. This linear trend model is applied to the data time series for each point that represents complete yearly data sets defined as encompassing at least 9 months of data per year. Otherwise, the location is discarded to avoid statistical inconsistencies. In general, the noise term can include random and systematic measurement errors and autocorrelation due to atmospheric variability (Weatherhead et al., 1998, 2002).

Figure 2 presents the linear trends of surface $\mathrm{CO}$ from MOPITT V5 TIR L3 products during daytime from 2001 to 2010. Here we have included all the MOPITT V5 data, including scenes that used water vapor climatology when the NCEP (National Centers for Environmental Prediction) Global Data Assimilation System (GDAS) product was not available. The use of water vapor climatology can produce anomalous results in the CO retrievals, as found by the MOPITT team, in particular, off the coast of California. Therefore, we do not have confidence in the higher $\mathrm{CO}$ values or trends that can be seen in this region in Figs. 1 and 2 .

An overall decrease of the surface $\mathrm{CO}$ from biomass burning over South America/Africa (Wallace and Hobbs, 2006; Liu et al., 2011) and fossil-fuel combustion over Eastern USA, Western Europe and Southeast Asia (Wallace and Hobbs, 2006; Liu et al., 2011; Buchwitz et al., 2007) is indicated. This tendency is consistent with the decreasing trends in total CO columns retrieved from MOPITT, the Atmospheric InfraRed Sounder (AIRS), the Tropospheric Emission Spectrometer (TES), and the Infrared Atmospheric Sounding Interferometer (IASI), which are reported in Worden et al. (2013a). However, the trends in Fig. 2 are affected by intrinsic uncertainty due to temporal changes of averaging kernels (AKs).

\section{Uncertainty from temporal change of averaging kernels}

The V5 MOPITT CO retrieval algorithm is based on the maximum a posteriori (MAP) that is an iterative optimal estimation technique (Pan et al., 1998; Rodgers, 2000; Deeter et al., 2003, 2010). The V5 algorithm employs the log (VMR: 


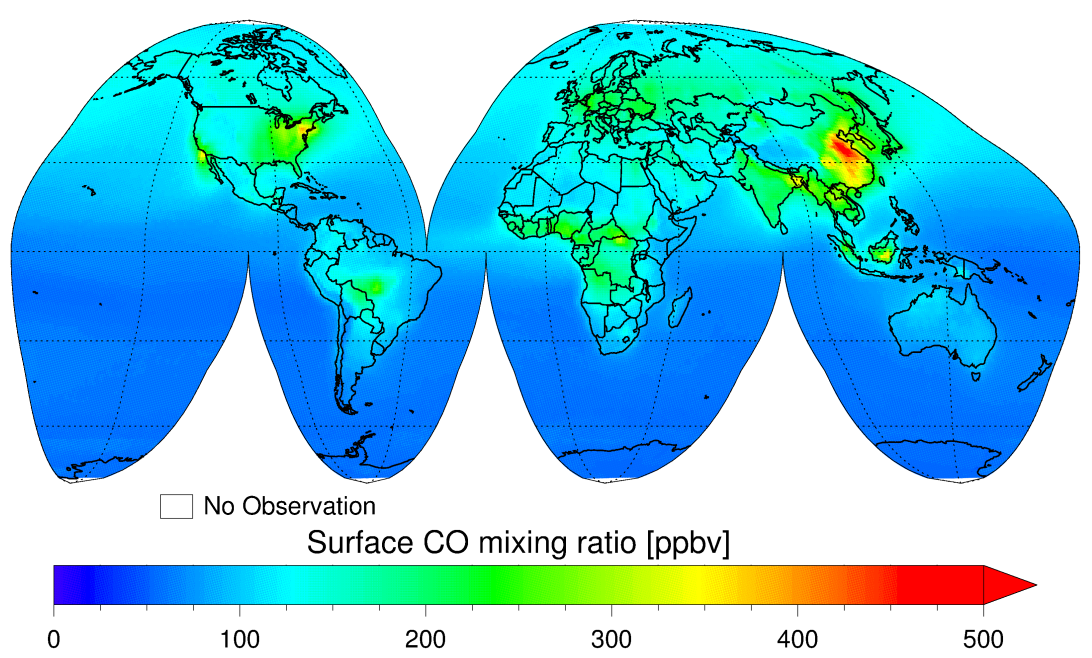

Fig. 1. Total mean distribution of global surface CO from MOPITT Version 5 TIR Level 3 product, referring to daytime from 2001 to 2010.

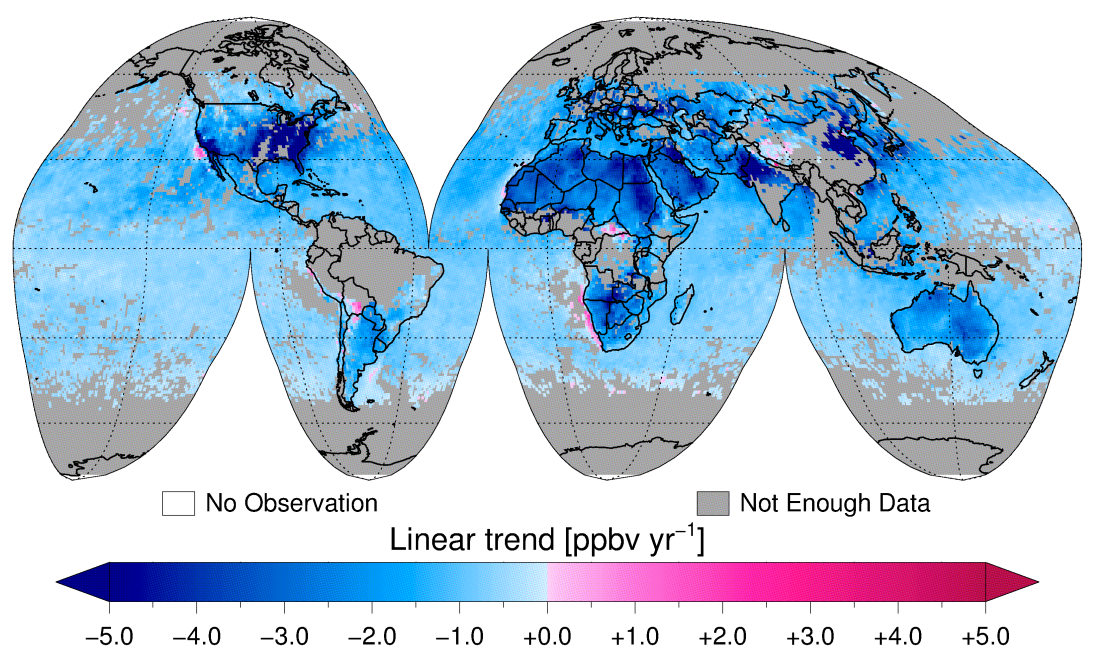

Fig. 2. The linear trends of surface CO from MOPITT (Version 5 TIR, Level 3, daytime) from 2001 to 2010. "Not Enough Data" represents the data series discarded to avoid statistical inconsistencies. Complete yearly data sets encompass at least nine months of data over the year.

Volume Mixing Ratio) retrievals (Deeter et al., 2013) that are the basis of this study. A statistical technique to solve the inversion problem is employed to find the optimal $\mathrm{CO}$ retrieval using the MOPITT measured radiances, based on a priori defined $\mathrm{CO}$ vertical profiles. If the forward model error is neglected, the relation equation between retrieved and true states can be expressed as follows (Rodgers, 1990; Pan et al., 1998; Deeter et al., 2003, 2010):

$\hat{\boldsymbol{x}} \cong \boldsymbol{x}_{0}+\mathbf{A}\left(\boldsymbol{x}-\boldsymbol{x}_{0}\right)=\mathbf{A} x+(\mathbf{I}-\mathbf{A}) \boldsymbol{x}_{0}$,

where $\hat{\boldsymbol{x}}, \boldsymbol{x}_{0}$, and $\boldsymbol{x}$ represent the retrieved, the a priori, and the true states of the atmosphere, respectively, which are arranged in 10 rows and 1 column for the 10 layers from surface to $100 \mathrm{hPa}$. A and I denote the AKs and identity matrices with 10 rows and 10 columns, respectively. For the surface layer, Eq. (2) is given as follows:

$$
\begin{aligned}
& \hat{\boldsymbol{x}}^{\text {surface }} \cong \mathrm{x}_{0}^{\text {surface }}+\mathbf{A}^{\text {surface }}\left(\boldsymbol{x}-\boldsymbol{x}_{0}\right) \\
& =\mathbf{A}^{\text {surface }} \boldsymbol{x}+\left(\mathbf{I}^{\text {surface }}-\mathbf{A}^{\text {surface }}\right) \boldsymbol{x}_{0},
\end{aligned}
$$

where $\hat{\boldsymbol{x}}^{\text {surface }}, \mathbf{x}_{0}^{\text {surface }}, \mathbf{I}^{\text {surface }}$ and $\mathbf{A}^{\text {surface }}$ represent the retrieved, the a priori surface $\mathrm{CO}$ data (arranged in 1 row and 1 column), the surface identity, and the surface AK (arranged in 1 row and 10 columns), respectively.

The AKs matrix (A), which reflects the sensitivity of the retrieved state to the true state, is the most important diagnostics of the retrieval (Pan et al., 1998; Rodgers, 2000; Deeter et al., 2003; Eskes and Boersma, 2003). When the AKs matrix is exactly equal to the identity matrix, the retrieved state is identical to the representation of the true atmospheric state on the altitude grid of the retrieval. However, in practice, the AKs matrix does not match up with I. For example, Fig. 3 


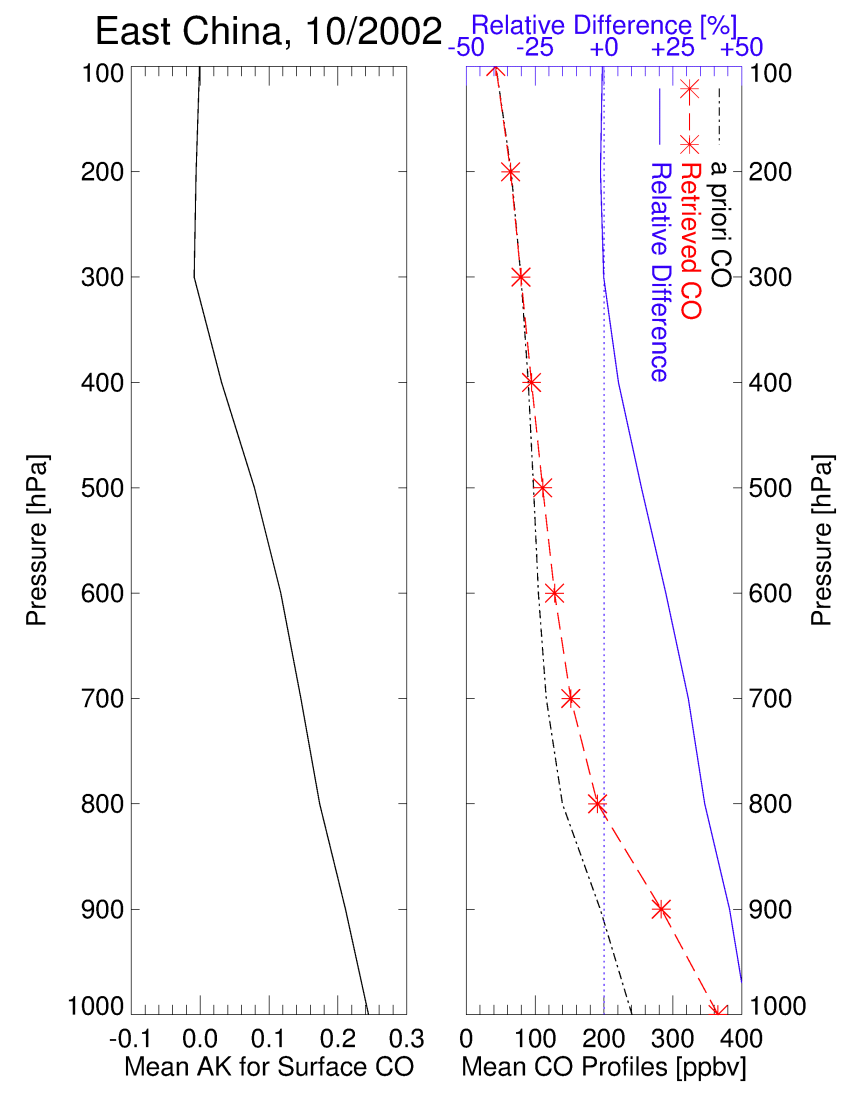

Fig. 3. Mean MOPITT averaging kernel for surface CO, a priori, and retrieved $\mathrm{CO}$ profiles over the grid cell defined by $30^{\circ} \mathrm{E}, 45^{\circ} \mathrm{E}$, $110^{\circ} \mathrm{N}$, and $120^{\circ} \mathrm{N}$ over East China on October 2002. The relative difference between retrieved $\mathrm{CO}$ with a priori profiles is shown to estimate the difference of true with a priori states $\left(\boldsymbol{x}-\boldsymbol{x}_{0}\right)$. The retrieved $\mathrm{CO}$ at the surface is about $52 \%$ higher than the a priori $\mathrm{CO}$ mixing ratio.

shows the mean AK for surface CO ( $\left.\mathbf{A}^{\text {surface }}\right)$, a priori $\left(\boldsymbol{x}_{0}\right)$, and retrieved $\mathrm{CO}$ profiles $(\hat{\boldsymbol{x}})$ over the grid cell defined by $30^{\circ} \mathrm{E}, 45^{\circ} \mathrm{E}, 110^{\circ} \mathrm{N}$, and $120^{\circ} \mathrm{N}$ in East China, where large quantities of $\mathrm{CO}$ are emitted into the atmosphere from the combustion of fossil fuels (see Fig. 1) (Liu et al., 2011; Buchwitz et al., 2007). The AK theoretically represents how much the true and a priori profiles contribute to the retrieved $\mathrm{CO}$ at the surface ( $\left.\hat{\boldsymbol{x}}^{\text {surface }}\right)$ as shown in Eq. (3). The surface retrieved CO is therefore the weighted mean contribution of the true $(\boldsymbol{x})$ and a priori profiles $\left(\boldsymbol{x}_{0}\right)$ in multiple layers. However, there is a clear difference between the a priori and retrieved $\mathrm{CO}$ profiles as shown in Fig. 3. For example, the retrieved $\mathrm{CO}$ at the surface is higher by about $52 \%$ compared to the a priori CO.

Most importantly, we are interested in the temporal change of the retrieved state, and its possible connection to the true trend. The retrieved trend can be expressed by the partial differential of Eq. (2) as follows:

$$
\begin{aligned}
& \frac{\partial \hat{\boldsymbol{x}}}{\partial t} \cong \frac{\partial \boldsymbol{x}_{0}}{\partial t}+\frac{\partial \mathbf{A}}{\partial t}\left(\boldsymbol{x}-\boldsymbol{x}_{0}\right)+\mathbf{A} \frac{\partial}{\partial t}\left(\boldsymbol{x}-\boldsymbol{x}_{0}\right) \\
& =(\mathbf{I}-\mathbf{A}) \frac{\partial \boldsymbol{x}_{0}}{\partial t}+\frac{\partial \mathbf{A}}{\partial t}\left(\boldsymbol{x}-\boldsymbol{x}_{0}\right)+\mathbf{A} \frac{\partial \boldsymbol{x}}{\partial t} .
\end{aligned}
$$

In the same manner, the trend of surface retrieved $\mathrm{CO}$ is given from Eq. (3) as follows:

$$
\begin{aligned}
& \frac{\partial \hat{\boldsymbol{x}}^{\text {surface }}}{\partial t} \cong \frac{\partial \mathbf{x}_{0}^{\text {surface }}}{\partial t}+\frac{\partial \mathbf{A}^{\text {surface }}}{\partial t}\left(\boldsymbol{x}-\boldsymbol{x}_{0}\right)+\mathbf{A}^{\text {surface }} \frac{\partial}{\partial t}\left(\boldsymbol{x}-\boldsymbol{x}_{0}\right) \\
& =\left(\mathbf{I}^{\text {surface }}-\mathbf{A}^{\text {surface }}\right) \frac{\partial \boldsymbol{x}_{0}}{\partial t}+\frac{\partial \mathbf{A}^{\text {surface }}}{\partial t}\left(\boldsymbol{x}-\boldsymbol{x}_{0}\right)+\mathbf{A}^{\text {surface }} \frac{\partial \boldsymbol{x}}{\partial t} .
\end{aligned}
$$

No temporal change is present in the a priori state (i.e., $\frac{\partial x_{0}}{\partial t}=0$ and $\left.\frac{\partial x_{0}^{\text {surface }}}{\partial t}=0\right)$, as it is obtained from a monthly climatology of the Model for Ozone and Related chemical Tracers-4 (MOZART-4), and does not represent interannual variability (Pan et al., 1998; Deeter et al., 2003; Deeter, 2009; Worden et al., 2013a). Therefore, Eqs. (4) and (5) can be rewritten as follows:

$$
\frac{\partial \hat{\boldsymbol{x}}}{\partial t} \cong \frac{\partial \mathbf{A}}{\partial t}\left(\boldsymbol{x}-\boldsymbol{x}_{0}\right)+\mathbf{A} \frac{\partial \boldsymbol{x}}{\partial t}
$$

and

$$
\frac{\partial \hat{\boldsymbol{x}}^{\text {surface }}}{\partial t} \cong \frac{\partial \mathbf{A}^{\text {surface }}}{\partial t}\left(\boldsymbol{x}-\boldsymbol{x}_{0}\right)+\mathbf{A}^{\text {surface }} \frac{\partial \boldsymbol{x}}{\partial t} .
$$

Again, if the AKs matrix is the identity matrix (i.e., $\mathbf{A}=\mathbf{I}$ in Eq. (7) and $\mathbf{A}^{\text {surface }}=\mathbf{I}^{\text {surface }}$ in Eq. 7), the temporal change of the retrieved state is the same as the change of the true state $\left(\frac{\partial \hat{x}}{\partial t}=\frac{\partial \boldsymbol{x}}{\partial t}\right.$ and $\frac{\partial \hat{x}^{\text {surface }}}{\partial t}=\frac{\partial x^{\text {surface }}}{\partial t}$ ). Even if the AKs matrix is not the identity matrix, but the AKs have no temporal change $\left(\mathbf{A} \neq \mathbf{I}\right.$, but $\frac{\partial \mathbf{A}}{\partial t}=0$ and $\mathbf{A}^{\text {surface }} \neq \mathbf{I}^{\text {surface }}$, but $\left.\frac{\partial \mathbf{A}^{\text {surface }}}{\partial t}=0\right)$ then the change of the retrieved state is an averaged contribution of the true changes in multiple layers $\left(\frac{\partial \hat{x}}{\partial t}=\mathbf{A} \frac{\partial \boldsymbol{x}}{\partial t}\right.$ and $\left.\frac{\partial \hat{\boldsymbol{x}}^{\text {surface }}}{\partial t}=\mathbf{A}^{\text {surface }} \frac{\partial \boldsymbol{x}}{\partial t}\right)$. In other words, no temporal change of $\operatorname{AKs}\left(\frac{\partial \mathbf{A}}{\partial t}=0\right.$ and $\left.\frac{\partial \mathbf{A}^{\text {surface }}}{\partial t}=0\right)$ is an ideal condition for the trend estimation. However in fact, the AKs do have a significant variability because they are influenced by all variables as inputs to the forward radiative transfer model (e.g., atmospheric temperature profile, surface pressure, and surface temperature) (Deeter et al., 2003). In addition, the changes in $\mathrm{AK}$ values over time are likely due to the changes in $\mathrm{CO}$ itself since retrieval sensitivity depends on $\mathrm{CO}$ amount as shown in Deeter et al. (2007b) and Worden et al. (2013b). Therefore, the trend of the retrieved state $\left(\frac{\partial \hat{\boldsymbol{x}}}{\partial t}\right.$ and $\left.\frac{\partial \hat{x}^{\text {surface }}}{\partial t}\right)$ can be biased by the term $\left(\frac{\partial \mathbf{A}}{\partial t}\left(\boldsymbol{x}-\boldsymbol{x}_{0}\right)\right.$ and $\left.\frac{\partial \mathbf{A}^{\text {surface }}}{\partial t}\left(\boldsymbol{x}-\boldsymbol{x}_{0}\right)\right)$, whose value (and even sign) is unknown, as the true state (and hence its difference with the a priori state) is unknown.

To estimate the general uncertainties caused by temporal varying $\mathrm{AKs}$, we make the assumption that the true state is $50 \%$ more (less) than the a priori state (i.e., $x=x_{0} \pm 50 \% \times$ $\boldsymbol{x}_{0}$ ). This $50 \%$ difference could be estimated from the difference between retrieved and a priori states at the surface as 
(a) Maximum

(b) Minimum
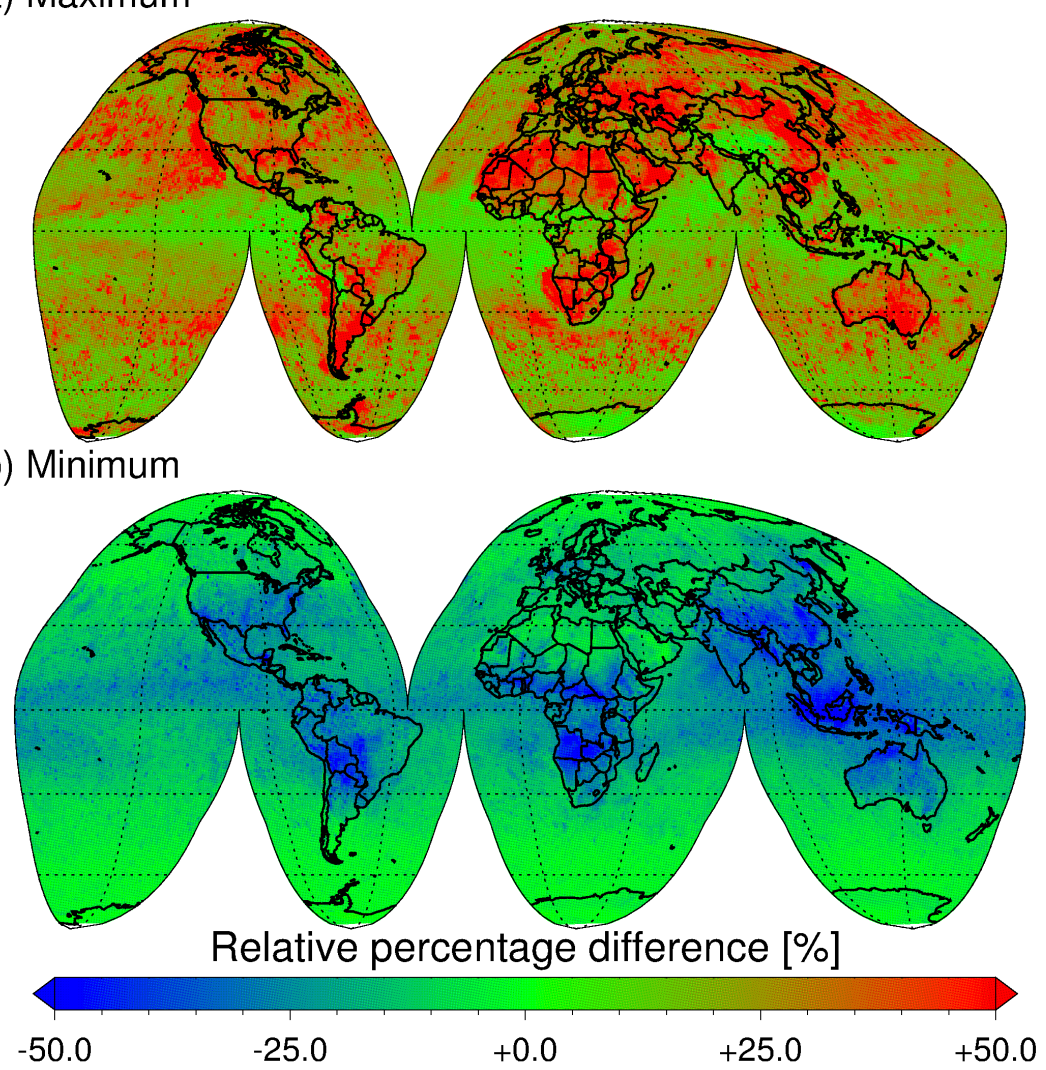

Fig. 4. Global distributions of (a) maximum and (b) minimum relative difference between retrieved and a priori CO at surface.

shown in Fig. 3. In addition, Fig. 4 shows the global distributions of maximum and minimum differences between them, and demonstrates that the assumption is reasonable globally. Eventually, the AKs uncertainty in the trend analysis of MOPITT CO at the surface is balancing between these extremes.

Following this assumption, the trend of the constructed "true state" is the same as the trend of the a priori state, which theoretically equals to zero (i.e. $\left.\frac{\partial x}{\partial t}=\frac{\partial x_{0}}{\partial t}=0\right)($ Pan et al., 1998; Deeter et al., 2003; Deeter, 2009; Worden et al., 2013a). Nevertheless, some significant trends of the hypothetically retrieved $\mathrm{CO}\left(\frac{\partial \hat{x}^{\text {surface }}}{\partial t}\right)$ at the surface are present, ranging from -10.71 to $+13.21 \mathrm{ppbv} \mathrm{yr}^{-1}(-5.68$ to $+8.84 \% \mathrm{yr}^{-1}$ ) in Fig. 5 . They are derived by fitting the hypothetically retrieved MOPITT surface $\mathrm{CO}$ (i.e., $\hat{\boldsymbol{x}}^{\text {surface }}=$ $\left.\mathrm{x}_{0}^{\text {surface }}+\mathbf{A}^{\text {surface }}\left( \pm 50 \% \times \boldsymbol{x}_{0}\right)\right)$ to Eq. (1). The largest deviation from a null trend is found over China where large surface $\mathrm{CO}$ emissions are reported (Liu et al., 2011; Buchwitz et al., 2007). Figure 5a is in contrast with Fig. 5b, as the difference between true and a priori state (i.e., $\left(\boldsymbol{x}-\boldsymbol{x}_{0}\right)$ in Eq. 7) is constant in both figures but with a different sign. In general, the magnitude of the uncertainty depends on the temporal AKs change $\left(\frac{\partial \mathbf{A}^{\text {surface }}}{\partial t}\right)$. For instance, in Fig. 5a, b when the difference is $-50 \% \times \boldsymbol{x}_{0}\left(+50 \% \times \boldsymbol{x}_{0}\right)$, the temporal increase of the $\mathrm{AK}$ for surface $\mathrm{CO}$ state force an under- (over-) estima- tion of the trends of retrieved state. Therefore, for both assumed conditions of true state (i.e., $x=x_{0} \pm 50 \% \times x_{0}$ ), the trend of the retrieved data is determined by the AKs trends multiplied by the difference between true and a priori states $\left(\frac{\partial \mathbf{A}^{\text {surface }}}{\partial t}\left(\boldsymbol{x}-\boldsymbol{x}_{0}\right)\right)$.

Since the true state (and hence its difference with the a priori state) is unknown, it is impossible to estimate the actual AKs uncertainty. Furthermore, this issue is relevant for all instrumentation and algorithms that rely on temporally varying AKs. Therefore, future trend studies using similar atmospheric sounding data like MOPITT retrievals, need to first check the temporal changes of AKs. Furthermore, because the difference between true and a priori states could be insignificant at higher level as shown in Fig. 3, the AKs uncertainty could be less than the expectation.

\section{Temporal variation of Level 3 a priori}

In Eqs. (6) and (7), we assumed that no trends are present in the a priori profiles (i.e., $\frac{\partial x_{0}}{\partial t}=0$ and $\frac{\partial x_{0}^{\text {surface }}}{\partial t}=0$ ). In fact, the a priori profiles are obtained from the MOZART4 model, which does not present an interannual variability (Pan et al., 1998; Deeter et al., 2003; Deeter, 2009; Worden et 

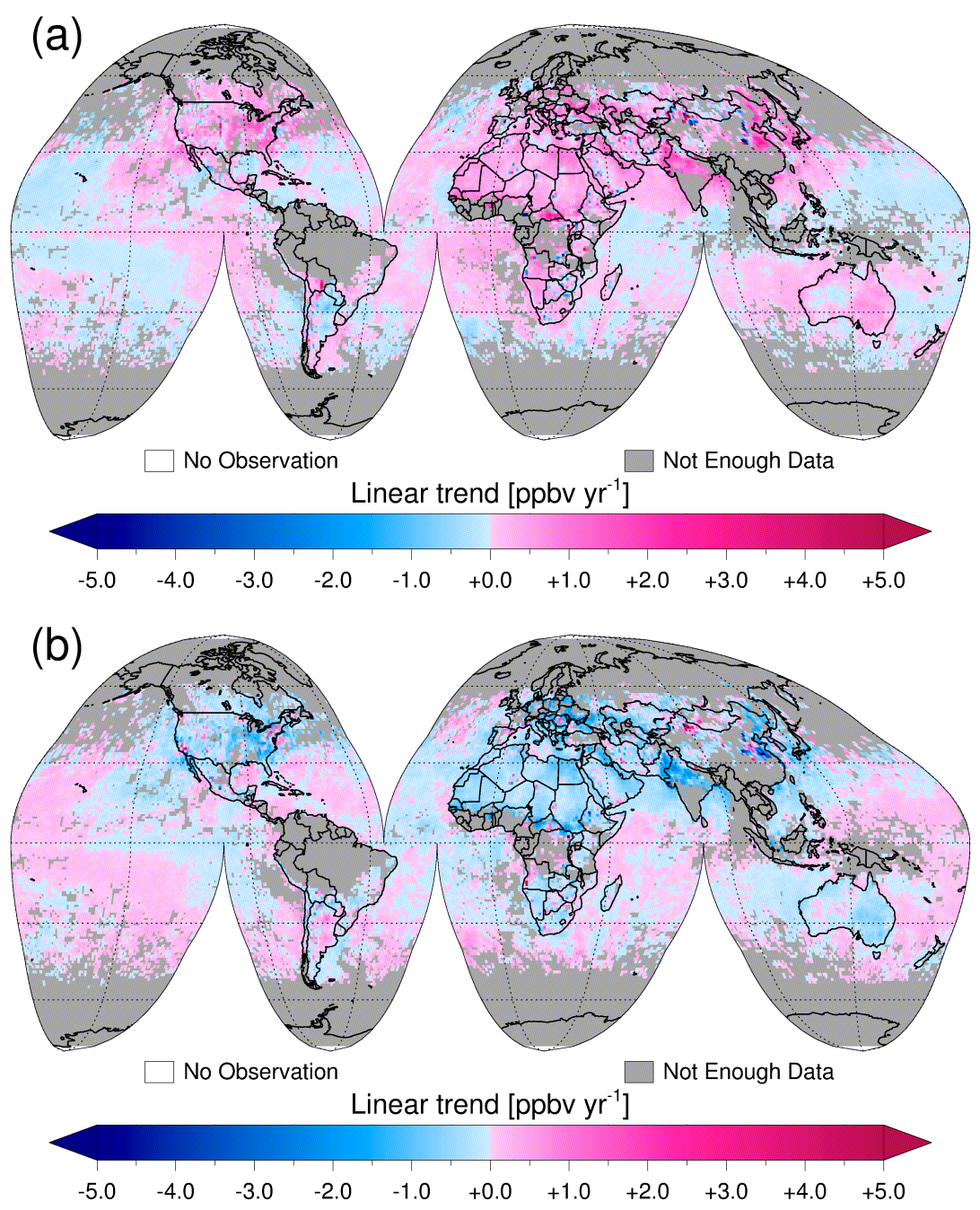

Fig. 5. The linear trends of retrieved states under the assumption that the true state is (a) $-50 \%$ or (b) $+50 \%$ higher than the a priori state (i.e., $\left.\boldsymbol{x}=\boldsymbol{x}_{0} \pm 50 \% \times \boldsymbol{x}_{0}\right)$. The trends of retrieved states range from -10.71 to $+13.21 \mathrm{ppbv} \mathrm{yr}^{-1}\left(-5.68\right.$ to $\left.+8.84 \% \mathrm{yr}^{-1}\right)$.

al., 2013a). Nevertheless, this is strictly valid only for Level 2 (daily) products, where the model climatology is spatially and temporally interpolated to the exact location and day of the observation for each retrieval (Deeter et al., 2010). In the Level 3 (monthly) data, instead, the surface a priori can have small temporal variation globally (i.e., $\frac{\partial x_{0}^{\text {surface }}}{\partial t} \neq 0$ ), as shown in Fig. 6a, even though it is negligible compared to the trend of retrieved surface $\mathrm{CO}\left(\frac{\partial \hat{x} \text { surface }}{\partial t}\right)$ (see Fig. 2). This small trend can be attributed to the mathematical/statistical aggregation (e.g., cloud filtering-out process) to monthly (Level 3) $1^{\circ} \times 1^{\circ}$ data. Figure $6 \mathrm{~b}$ shows the MOPITT a priori CO at the surface between 2001 and 2010 for the location where the highest trend of the a priori $\mathrm{CO}$ is present

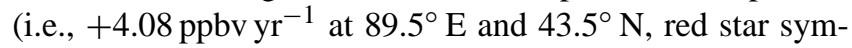
bol in Fig. 6a). The anomaly of surface a priori $\mathrm{CO}$ (i.e., the difference between surface a priori and seasonal mean) includes an interannual variability and a net distinction in 2005 .
Hence not only does the temporal variation of Level 3 a priori data make it more difficult to predict the difference between true and a priori states (i.e., $\left.\left(\boldsymbol{x}-\boldsymbol{x}_{0}\right)\right)$, it also creates the additional uncertainty $\left((\mathbf{I}-\mathbf{A}) \frac{\partial x_{0}}{\partial t}\right.$ and $\left.\left(\mathbf{I}^{\text {surface }}-\mathbf{A}^{\text {surface }}\right) \frac{\partial x_{0}}{\partial t}\right)$ in the trend estimation as shown in Eqs. (4) and (5).

\section{Summary and conclusions}

Time varying AKs have been shown to be a significant source of uncertainties/errors in the estimation of temporal variation in retrieved data. The uncertainty test applied in this study, based on the MOPITT V5 TIR Level 3 CO products at the surface, demonstrates that the temporal changes of AKs and the differences between true and a priori states can cause significant uncertainties in the trend estimation. Unfortunately, it is not possible to eliminate the AKs uncertainty solely based on satellite observations, as the true state 


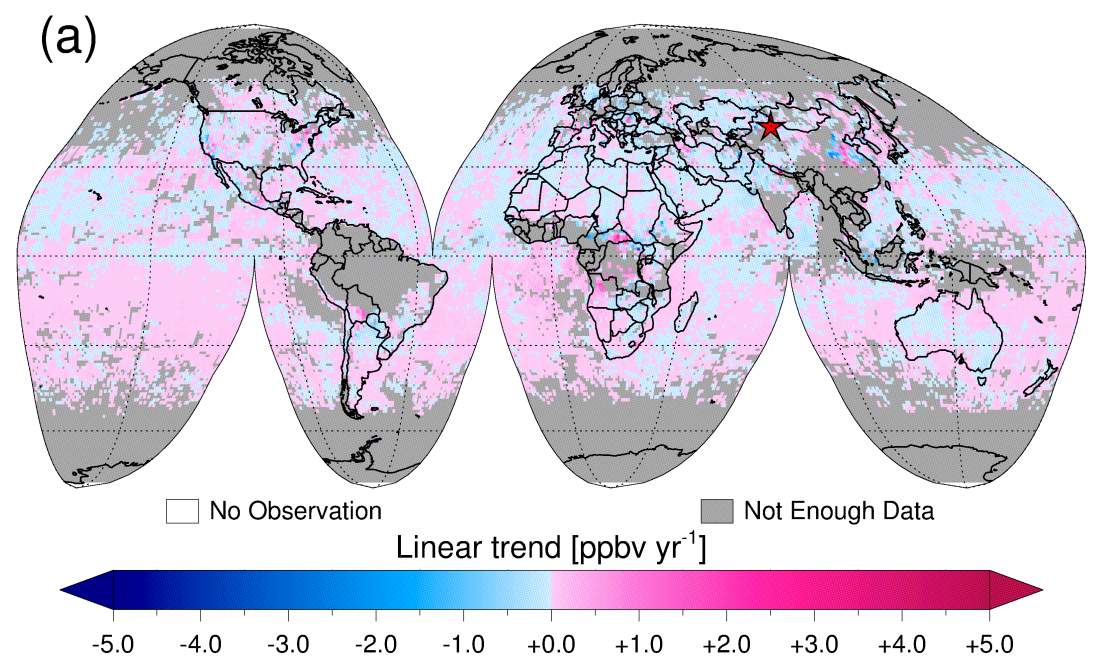

(b)

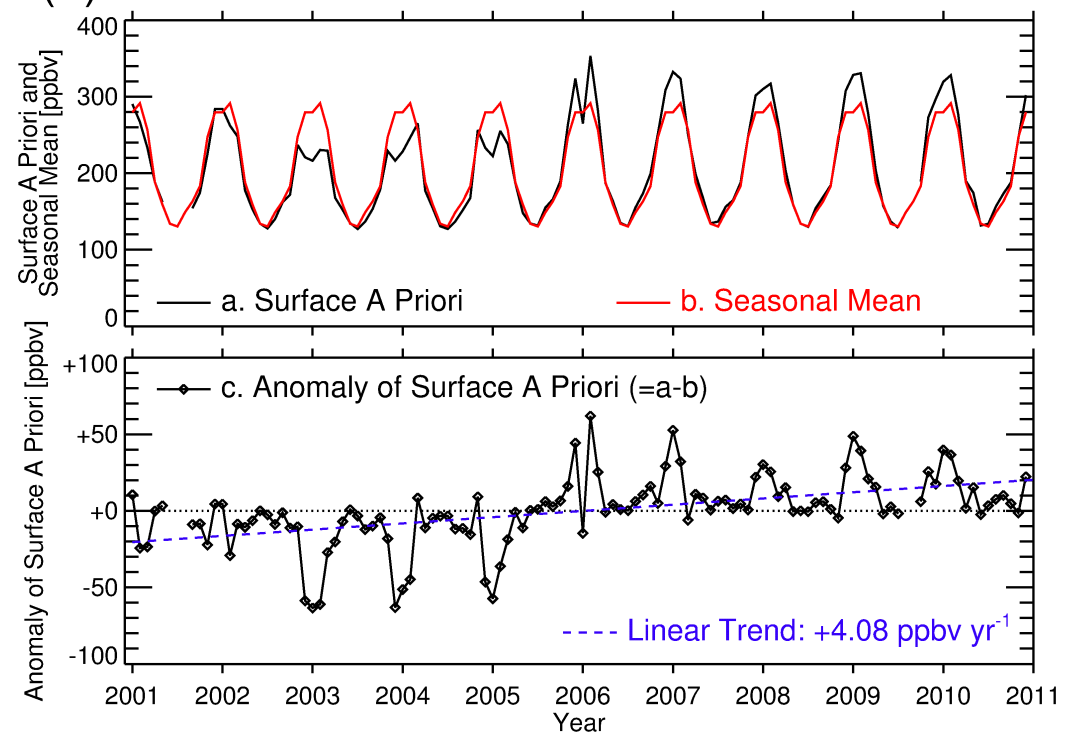

Fig. 6. (a) The linear trends of surface a priori CO from MOPITT (V5 TIR Level 3) (daytime) from 2001 to 2010 ; the coordinates $89.5^{\circ} \mathrm{E}$ and $43.5^{\circ} \mathrm{N}$ are marked by a red star symbol; (b) MOPITT surface a priori and the seasonal CO are depicted. The anomaly of surface a priori $\mathrm{CO}$ shows that it varies considerably with time.

is unknown. Retrieved total column CO product might also be affected, since it is the vertical integral of the retrieved $\mathrm{CO}$ profiles (Worden et al., 2013a). However, the related uncertainties at high altitudes are expected to be smaller than for the near-surface layers because of smaller difference between the true and a priori state. Future studies should investigate this aspect. Furthermore, trend studies based on satellite- and ground-based data products, which have been derived using similar atmospheric sounding methods like the MOPITT retrieval, need to carefully estimate uncertainties and errors that may be caused by time varying AKs.
Acknowledgements. The authors would like to thank the NASA Langley Research Center (Atmospheric Science Data Center, https://eosweb.larc.nasa.gov/project/mopitt/mopitt_table) for providing the MOPITT Version 5 TIR Level 3 products used in the study. The work of Peter Hoor and Sebastian Schlögl was funded by the German French DFG/INSU-CNRS project POMODORO.

The service charges for this open access publication have been covered by the Max Plank Society.

Edited by: T. von Clarmann 


\section{References}

Arellano, A. F. and Hess, P. G.: Sensitivity of top-down estimates of CO sources to GCTM transport, Geophys. Res. Lett., 33, L21807, doi:10.1029/2006GL027371, 2006.

Buchwitz, M., Khlystova, I., Bovensmann, H., and Burrows, J. P.: Three years of global carbon monoxide from SCIAMACHY: comparison with MOPITT and first results related to the detection of enhanced CO over cities, Atmos. Chem. Phys., 7, 23992411, doi:10.5194/acp-7-2399-2007, 2007.

Burrows, J. P., Hölzle, E., Goede, A. P. H., Visser, H., and Fricke, W.: SCIAMACHY - Scanning Imaging Absorption Spectrometer for Atmospheric Chartography, Acta Astron., 35, 445-451, 1995.

Burrows, J. P., Goede, A. P. H., Muller, C., and Bovensmann, H.: SCIAMACHY - The Need for Atmospheric Research from Space, in: SCIAMACHY - Exploring the Changing Earth's Atmosphere, edited by: Gottwald, M. and Bovensmann, H., Springer Science + Business Media B.V., Dordrecht, Netherlands, 1-17, doi:10.1007/978-90-481-9896-2_1, 2011.

Choi, S. D. and Chang, Y. S.: Carbon monoxide monitoring in Northeast Asia using MOPITT: Effects of biomass burning and regional pollution in April 2000, Atmos. Environ., 40, 686-697, doi:10.1016/j.atmosenv.2005.09.081, 2006.

Cicerone, R. J.: How has the Atmospheric Concentration of CO changed, in: The Changing Atmosphere, edited by: Rowland, F. S., and Isaksen, I. S. A., Wiley, Chicester, UK, 49-61, 1988.

Clerbaux, C., Boynard, A., Clarisse, L., George, M., Hadji-Lazaro, J., Herbin, H., Hurtmans, D., Pommier, M., Razavi, A., Turquety, S., Wespes, C., and Coheur, P.-F.: Monitoring of atmospheric composition using the thermal infrared IASI/MetOp sounder, Atmos. Chem. Phys., 9, 6041-6054, doi:10.5194/acp-9-6041-2009, 2009.

Crutzen, P. J.: Photochemical reactions initiated by and influencing ozone in unpolluted tropospheric air, Tellus, 26, 47-57, 1974.

Crutzen, P. J. and Gidel, L. T.: A two-dimensional photochemical model of the atmosphere. 2: The tropospheric budgets of anthropogenic chlorocarbons $\mathrm{CO}, \mathrm{CH}_{4}, \mathrm{CH}_{3} \mathrm{Cl}$ and the effect of various. $\mathrm{NO}_{x}$ sources on tropospheric ozone, J. Geophys. Res., 88, 6641-6661, 1983.

Deeter, M. N.: MOPITT (Measurements of Pollution in the Troposphere) Validated Version 4 Product User's Guide, http://www. acd.ucar.edu/mopitt/v4_users_guide_val.pdf, 1-21, May, 2009.

Deeter, M. N., Emmons, L. K., Francis, G. L., Edwards, D. P., Gille, J. C., Warner, J. X., Khattatov, B., Ziskin, D., Lamarque, J.-F., Ho, S.-P., Yudin, V., Attié, J.-L., Packman, D., Chen, J., Mao, D., and Drummond, J. R.: Operational carbon monoxide retrieval algorithm and selected results for the MOPITT instrument, J. Geophys. Res., 108, 4399, doi:10.1029/2002JD003186, 2003.

Deeter, M. N., Edwards, D. P., Gille, J. C., and Drummond, J. R.: Sensitivity of MOPITT observations to carbon monoxide in the lower troposphere, J. Geophys. Res., 112, 24306, doi:10.1029/2007JD008929, 2007a.

Deeter, M. N., Edwards, D. P., and Gille, J. C.: Retrievals of carbon monoxide profiles from MOPITT observations using lognormal a priori statistics, J. Geophys. Res., 112, D11311, doi:10.1029/2006JD007999, 2007b.

Deeter, M. N., Edwards, D. P., Gille, J. C., Emmons, L. K., Francis, G., Ho, S.-P., Mao, D., Masters, D., Worden, H., Drummond, J. R., and Novelli, P. C.: The MOPITT version 4 CO product:
Algorithm enhancements, validation, and long-term stability, J. Geophys. Res., 115, D07306, doi:10.1029/2009JD013005, 2010.

Deeter, M. N., Worden, H. M., Gille, J. C., Edwards, D. P., Mao, D., and Drummond, J. R.: MOPITT multispectral CO retrievals: Origins and effects of geophysical radiance errors, J. Geophys. Res., 116, D15303, doi:10.1029/2011JD015703, 2011.

Deeter, M. N., Worden, H. M., Edwards, D. P., Gille, J. C., and Andrews, A. E.: Evaluation of MOPITT Retrievals of Lowertropospheric Carbon Monoxide over the United States, J. Geophys. Res., 117, D13306, doi:10.1029/2012JD017553, 2012.

Deeter, M. N., Martínez-Alonso, S., Edwards, D. P., Emmons, L. K., Gille, J. C., Worden, H. M., Pittman, J. V., Daube, B. C., and Wofsy, S. C.: Validation of MOPITT Version 5 thermalinfrared, near-infrared, and multispectral carbon monoxide profile retrievals for 2000-2011, J. Geophys. Res., 118, 1-16, doi:10.1002/jgrd.50272, 2013.

Drori, R., Dayan, U., Edwards, D. P., Emmons, L. K., and Erlick, C.: Attributing and quantifying carbon monoxide sources affecting the Eastern Mediterranean: a combined satellite, modelling, and synoptic analysis study, Atmos. Chem. Phys., 12, 1067-1082, doi:10.5194/acp-12-1067-2012, 2012.

Edwards, D. P., Emmons, L. K., Hauglustaine, D. A., Chu, A., Gille, J. C., Kaufman, Y. J., Pétron, G., Yurganov, L. N., Giglio, L., Deeter, M. N., Yudin, V., Ziskin, D. C., Warner, J., Lamarque, J.F., Francis, G. L., Ho, S. P., Mao, D., Chan, J., and Drummond, J. R.: Observations of Carbon Monoxide and Aerosol From the Terra Satellite: Northern Hemisphere Variability, J. Geophys. Res., 109, D24202, doi:10.1029/2004JD0047272004, 2004.

Edwards, D. P., Emmons, L. K., Gille, J. C., Chu, A., Attié, J.-L., Giglio, L., Wood, S. W., Haywood, J., Deeter, M. N., Massie, S. T., Ziskin, D. C., and Drummond, J. R.: Satellite-observed pollution from Southern Hemisphere biomass burning, J. Geophys. Res., 111, 14312, doi:10.1029/2005JD006655, 2006.

Eskes, H. J. and Boersma, K. F.: Averaging kernels for DOAS totalcolumn satellite retrievals, Atmos. Chem. Phys., 3, 1285-1291, doi:10.5194/acp-3-1285-2003, 2003.

Fishman, J. and Crutzen, P. J.: the origin of ozone in the troposphere, nature, 274, 855-858, 1978.

Forster, P., Ramaswamy, V., Artaxo, P., Berntsen, T., Betts, R., Fahey, D. W., Haywood, J., Lean, J., Lowe, D. C., Myhre, G., Nganga, J., Prinn, R., Raga, G., Schulz, M., and Van Dorland, R.: Changes in Atmospheric Constituents and in Radiative Forcing, in: Climate Change 2007: The Physical Science Basis. Contribution of Working Group I to the Fourth Assessment Report of the Intergovernmental Panel on Climate Change, edited by: Solomon, S., Qin, D., Manning, M., Chen, Z., Marquis, M., Averyt, K. B., Tignor, M., and Miller, H. L., Cambridge University Press, Cambridge, UK and New York, NY, USA, 129-234, 2007.

Fortems-Cheiney, A., Chevallier, F., Pison, I., Bousquet, P., Szopa, S., Deeter, M. N., and Clerbaux, C.: Ten years of $\mathrm{CO}$ emissions as seen from Measurements of Pollution in the Troposphere (MOPITT), J. Geophys. Res., 116, D05304, doi:10.1029/2010JD014416, 2011.

Hansen, J., Sato, M., Kharecha, P., Russell, G., Lea, D. W., and Siddall, M.: Climate change and trace gases, Phil. Trans. R. Soc. A, 365, 1925-1954, doi:10.1098/rsta.2007.2052, 2007.

Hooghiemstra, P. B., Krol, M. C., Meirink, J. F., Bergamaschi, P., van der Werf, G. R., Novelli, P. C., Aben, I., and Röckmann, T.: Optimizing global $\mathrm{CO}$ emission estimates using a 
four-dimensional variational data assimilation system and surface network observations, Atmos. Chem. Phys., 11, 4705-4723, doi:10.5194/acp-11-4705-2011, 2011.

Hoor, P., Fischer, H., and Lelieveld, J.: Tropical and extratropical tropospheric air in the lowermost stratosphere over Europe: A CO based budget, Geophys. Res. Lett., 32, L07802, doi:10.1029/2004GL022018, 2005.

Kanakidou, M., Mihalopoulos, N., Kindap, T., Im, U., Vrekoussis, M., Gerasopoulos, E., Dermitzaki, E., Unal, A., Koçak, M., Markakis, K., Melas, D., Kouvarakis, G., Youssef, A. F., Richter, A., Hatzianastassiou, N., Hilboll, A., Ebojie, F., Wittrock, F., von Savigny, C., Burrows, j. P., Ladstaetter-Weissenmayer, A., and Moubasher, H.: Megacities as hot spots of air pollution in the East Mediterranean, Atmos. Environ., 45, 6, 1223-1235, doi:10.1016/j.atmosenv.2010.11.048, 2011.

Khalil, M. A. K. and Rasmussen, R. A.: The global cycle of carbon monoxide: trends and mass balance, Chemosphere, 20, 227-242, 1990.

Lelieveld, J., Crutzen, P. J., Andreae, M. O., Brenninkmeijer, C. A. M., Campos, T., Cass, G. R., Dickerson, G. R., Fischer, H., de Gouw, J. A., Hansel, A., Jefferson, A., Kley, D., de Laat, A. T. J., Lal, S., Lawrence, M. G., Lobert, J. M., Mayol-Bracero, O., Mitra, A. P., Novakov, T., Oltmans, S. J., Prather, K. A., Ramanathan, V., Reiner, T., Rodhe, H., Scheeren, H. A., Sikka, D., and Williams, J.: The Indian Ocean Experiment: Widespread air pollution from South and South-East Asia, Science, 291, 10311036, 2001.

Liu, C., Beirle, S., Butler, T., Liu, J., Hoor, P., Jöckel, P., Penning de Vries, M., Pozzer, A., Frankenberg, C., Lawrence, M. G., Lelieveld, J., Platt, U., and Wagner, T.: Application of SCIAMACHY and MOPITT CO total column measurements to evaluate model results over biomass burning regions and Eastern China, Atmos. Chem. Phys., 11, 6083-6114, doi:10.5194/acp11-6083-2011, 2011.

Liu, C., Beirle, S., Butler, T., Hoor, P., Frankenberg, C., Jöckel, P., Penning de Vries, M., Platt, U., Pozzer, A., Lawrence, M. G., Lelieveld, J., Tost, H., and Wagner, T.: CO profiles from SCIAMACHY observations using cloud slicing and comparison with model simulations, Atmos. Chem. Phys. Discuss., 13, 1165911688, doi:10.5194/acpd-13-11659-2013, 2013.

Logan, J. A., Prather, M. J., Wofsy, S. C., and Mcelroy, M. B.: Tropospheric Chemistry - a Global Perspective, J. Geophys. Res., 86, C8, 7210-7254, 1981.

Pan, L., Edwards, D. P., Gille, J. C., Smith, M. W., and Drummond, J. R.: Satellite remote sensing of tropospheric $\mathrm{CO}$ and $\mathrm{CH}_{4}$ : forward model studies of the MOPITT instrument, Applied Optics, 34, 30, 6976-6988, doi:10.1364/AO.34.006976, 1995.

Pan, L., Gille, J. C., Edwards, D. P., Bailey, P. L., and Rodgers, C. D.: Retrieval of tropospheric carbon monoxide for the MOPITT experiment, J. Geophys. Res., 103, 32277-32290, doi:10.1029/98JD01828, 1998.

Rodgers, C. D.: Retrieval of atmospheric temperature and composition from remote measurements of thermal radiation, Rev. Geophys., 14, 4, 609-624, doi:10.1029/RG014i004p00609, 1976.

Rodgers, C. D.: Characterization and error analysis of profiles retrieved from remote sounding measurements, J. Geophys. Res., 95, D5, 5587-5595, doi:10.1029/JD095iD05p05587, 1990.
Rodgers, C. D.: Inverse methods for atmospheric sounding - theory and practice, Series on Atmospheric, Oceanic and Planetary Physics, World Scientific Publishing, Singapore, 2000.

Rodgers, C. D. and Connor, B. J.: Intercomparison of Remote Sounding Instruments, J. Geophys. Res., 108, 4116, doi:10.1029/2002JD002299, 2003.

Shindell, D. T., Faluvegi, G., Stevenson, D. S., Krol, M. C., Emmons, L. K., Lamarque, J. F., Petron, G., Dentener, F. J., Ellingsen, K., Schultz, M. G., Wild, O., Amann, M., Atherton, C. S., Bergmann, D. J., Bey, I., Butler, T., Cofala, J., Collins, W. J., Derwent, R. G., Doherty, R. M., Drevet, J., Eskes, H. J., Fiore, A. M., Gauss, M., Hauglustaine, D. A., Horowitz, L. W., Isaksen, I. S. A., Lawrence, M. G., Montanaro, V., Muller, J. F., Pitari, G., Prather, M. J., Pyle, J. A., Rast, S., Rodriguez, J. M., Sanderson, M. G., Savage, N. H., Strahan, S. E., Sudo, K., Szopa, S., Unger, N., van Noije, T. P. C., and Zeng, G.: Multimodel simulations of carbon monoxide: Comparison with observations and projected near-future changes, J. Geophys. Res., 111, D19306, doi:10.1029/2006JD007100, 2006.

Stroppiana, D., Brivio, P. A., Grégoire, J.-M., Liousse, C., Guillaume, B., Granier, C., Mieville, A., Chin, M., and Pétron, G.: Comparison of global inventories of $\mathrm{CO}$ emissions from biomass burning derived from remotely sensed data, Atmos. Chem. Phys., 10, 12173-12189, doi:10.5194/acp-10-12173-2010, 2010.

University of Toronto and NCAR MOPITT Team: MOPITT (Measurement of Pollution in the Troposphere) Level 1 Algorithm Theoretical Basis Documents, ATBD-MOP-01, University of Toronto and NCAR MOPITT Team, http://eospso.gsfc.nasa.gov/ sites/default/files/atbd/atbd-mop-01.pdf, 1-45, August, 1996.

Wallace, J. M. and Hobbs, P. V.: Atmospheric Chemistry. In: Atmospheric Science, Second Edition: An Introductory Survey, edited by: Dmowska, R., Hartmann, D., and Rossby, H. T., Elsevier, MA, USA, California, USA and London, UK, 153-207, 2006.

Weatherhead, E. C., Reinsel, G. C., Tiao, G. C., Meng, X.-L., Choi, D., Cheang, W.-K., Keller, T., DeLuisi, J., Wuebbles, D. J., Kerr, J. B., Miller, A. J., Oltmans, S. J., and Frederick, J. E.: Factors affecting the detection of trends: Statistical considerations and applications to environmental data, J. Geophys. Res., 103, 1714917161, doi:10.1029/98JD00995, 1998.

Weatherhead, E. C., Stevermer, A. J., and Schwartz, B. E.: Detecting environmental changes and trends, Physics and Chemistry of the Earth, 27, 399-403, doi:10.1016/S1474-7065(02)00019-0, 2002.

Worden, H. M., Deeter, M. N., Edwards, D. P., Gille, J. C., Drummond, J. R., and Nédélec, P. P.: Observations of near-surface carbon monoxide from space using MOPITT multispectral retrievals, J. Geophys. Res., 115, D18314, doi:10.1029/2010JD014242, 2010.

Worden, H. M., Deeter, M. N., Frankenberg, C., George, M., Nichitiu, F., Worden, J., Aben, I., Bowman, K. W., Clerbaux, C., Coheur, P. F., de Laat, A. T. J., Detweiler, R., Drummond, J. R., Edwards, D. P., Gille, J. C., Hurtmans, D., Luo, M., MartínezAlonso, S., Massie, S., Pfister, G., and Warner, J. X.: Decadal record of satellite carbon monoxide observations, Atmos. Chem. Phys., 13, 837-850, doi:10.5194/acp-13-837-2013, 2013a.

Worden, H. M., Edwards, D. P., Deeter, M. N., Fu, D., Kulawik, S. S., Worden, J. R., and Arellano, A.: Averaging kernel prediction from atmospheric and surface state parameters based on multiple regression for nadir-viewing satellite measurements of car- 
bon monoxide and ozone, Atmos. Meas. Tech., 6, 1633-1646,

doi:10.5194/amt-6-1633-2013, 2013b. 